\title{
Movements of green turtles from foraging areas of the United Arab Emirates: regional habitat connectivity and use of marine protected areas
}

\author{
Nicolas James Pilcher ${ }^{1}$ (D) Marina A. Antonopoulou ${ }^{2}$. Clara Jimena Rodriguez-Zarate ${ }^{2}$. Daniel Mateos-Molina ${ }^{2}$. \\ Himansu Sekhar Das ${ }^{3}$. Ibrahim Bugla ${ }^{3}$. Saif Mohammed Al Ghais ${ }^{4}$
}

Received: 22 June 2020 / Accepted: 14 December 2020 / Published online: 7 January 2021

(c) The Author(s) 2020

\begin{abstract}
Adult sea turtles migrate between foraging areas and nesting sites that may be $100 \mathrm{~s}-1000 \mathrm{~s}$ of km away. Little is known of the connectivity between these sites in the Arabian region for green sea turtles. We document linkages between two foraging areas in the United Arab Emirates (UAE) with key nesting sites and provide insights on effectiveness of marine protected areas for green sea turtles. Tracking 45 adult green sea turtles Chelonia mydas from foraging areas in the UAE, we show that the primary nesting destination for turtles foraging in Bu Tinah in the UAE is Ras al Hadd in Oman. The turtles use the waters of the UAE, Iran and Oman during breeding migrations and generally stay $20 \mathrm{~km}$ off the coast, in waters 10-20 m deep except when crossing the Sea of Oman. Turtles display substantial fidelity to the original foraging sites, often traversing other known foraging sites when returning from the breeding migration. A small proportion of turtles also utilise more than one foraging site. Our data indicate that the Marawah Marine Biosphere Reserve in Abu Dhabi is broadly coincident with the foraging areas of turtles offering substantial protection from fishery activities and that the marine protected area in Ras $\mathrm{Al}$ Khaimah would be more effective in protecting green sea turtles if it extended offshore and along the coast. These data may contribute to targeted and effective national and international management and conservation initiatives in the Arabian region.
\end{abstract}

Responsible Editor: P. Casale.

Reviewed by undisclosed experts.

Supplementary Information The online version contains supplementary material available at https://doi.org/10.1007/s0022 7-020-03815-6.

Nicolas James Pilcher

npilcher@mrf-asia.org

1 Marine Research Foundation, 136 Lorong Pokok Seraya 2, Taman Khidmat, 88450 Kota Kinabalu, Sabah, Malaysia

2 Emirates Nature - WWF, Dubai, United Arab Emirates

3 Environment Agency Abu Dhabi, Dubai, United Arab Emirates

4 Environmental Protection and Development Authority, Ras Al Khaimah, Dubai, United Arab Emirates

\section{Introduction}

In the Arabian region, there are large green turtle nesting sites in Oman (3000-6000 females year ${ }^{-1}$ : Ross and Barwani 1982), Saudi Arabia ( 1000 females year ${ }^{-1}$ : Miller 1989; Pilcher 2000) and Yemen (5000-8000 females year ${ }^{-1}$ : Saad 1999; Nasher and Al Jumaily 2015). Significantly smaller nesting sites $\left(<25\right.$ females year $\left.^{-1}\right)$ exist in Kuwait (Rees et al. 2013) and Iran, where green turtle nesting is rare. One green turtle nest was reported on Sheedvar Island (Mobaraki et al. 2019) and another at Cholotr, facing the Sea of Oman (Mobaraki 2004). Unquantified green turtle nesting also reportedly occurs on Kharku Island and at Chahbahar. In the United Arab Emirates nesting by green turtles is similarly rare: Miller et al. (2004) reported isolated nesting by green turtles on UAE islands; one nest was recorded on Sir Bu Nair island inside of the Gulf (Al-Suweidi et al. 2012) and one other at Khor Kalba in the Gulf of Oman (Hebbelmann et al. 2016). Green turtles are, however, extremely abundant in UAE waters and there are well-known foraging areas off Abu Dhabi (EAD 2007) and Ras Al Khaimah (Hasbún et al. 2000). Seagrass habitats, where green turtles feed, 
are extensive across much of the southwest Arabian Gulf (Phillips 2003), and these likely support additional foraging green turtle assemblages (e.g., western Abu Dhabi, Sharjah).

Sea turtles spend an inordinate proportion of their lives in foraging areas while in juvenile and sub-adult developmental stages, and later as reproductive adults (Musick and Limpus 1997). However, far less is known about the life history of turtles in foraging areas given the challenges in conducting studies in the vast marine environment across which they are dispersed. These studies require greater resource investment (e.g., boats, in-water captures, transport) or opportunistic acquisition (e.g., from bycatch events). Most sea turtle studies have thus focused primarily on post-nesting females (Godley et al. 2008), as this life stage is logistically easy to work with. However, at-sea studies have gained traction in the past decade as greater effort has been invested in understanding foraging, and male, turtle population segments. Satellite tracking has revealed that nesting sites may host turtles originating from multiple foraging areas (e.g., Limpus et al. 1992; Bjorndal et al. 2005), and foraging areas may be home to turtles from multiple nesting sites (e.g. Casale et al. 2008; Carreras et al. 2011). Satellite tracking has also revealed connectivity between foraging areas and breeding sites (e.g., male loggerhead turtles Caretta caretta in the Mediterranean; Casale et al. 2013), and this information is useful in designing conservation measures. For example, understanding foraging area habitat use and extent can aid in the development of marine protected areas (e.g., Schofield et al 2013). Sea turtles display substantial fidelity to foraging sites, often bypassing other foraging areas on the return from breeding migrations (e.g., Australia; Shimada et al. 2020). Foraging areas can change seasonally, and fidelity to these sites across years can be high (Mingozzi et al 2016). Foraging areas can also host mixed age-classes of sea turtles (e.g., in the Republic of the Congo; Metcalfe et al. 2010) and this distribution is likely regulated by resource availability and competition. Expanding on the potential results from satellite tracking post-nesting female turtles, satellite tracking studies from foraging areas have the incremental ability to (a) document links from foraging areas to unknown nesting destinations (e.g., Dutton et al. 2018); (b) document round trip foraging-nesting-foraging migrations (e.g., Limpus and Limpus 2001); (c) document use of multiple foraging areas (e.g., Casale et al 2012a); (d) document movements of male turtles (e.g., James et al. 2005); and (e) of juvenile turtles (e.g., Hart and Fujisaki 2010), along with similar habitat use, migratory corridor and habitat connectivity data.

Sea turtles migrate from established foraging areas to distant nesting sites (Musick and Limpus 1997), and these migrations may be short $(<100 \mathrm{~km}$, e.g., Arabian Gulf hawksbills; Pilcher et al. 2014a), or may exceed 10,000 km (e.g., Pacific leatherbacks; Benson et al. 2007) and generally involve crossing sovereign boundaries. Connectivity between foraging areas and nesting sites needs to be taken into account in conservation and management practices, and documenting these links, particularly when sea turtles cross international boundaries, is an important requirement for targeted conservation (Martin et al. 2007; Hamann et al. 2010; Dunn et al. 2019). This is particularly relevant in the Arabian region, where little is known of the connectivity between nesting sites and foraging areas for green turtles, or of the overlap between existing Marine Protected Areas (MPAs) and sea turtle distribution. There is little known on the connectivity between these habitats within the Arabian region for green sea turtles. Studies have documented movements of a small number of green sea turtles from nesting sites in Oman (Rees et al. 2012), Kuwait (Rees et al. 2013, 2019) and Saudi Arabia (Maneja et al. 2018), and of rehabilitated turtles in the United Arab Emirates (Robinson et al. 2017). Tag returns are rare and generally unreported publicly. Genetic studies on green sea turtles in the Arabian region that could also identify habitat linkages are similarly limited (Jensen et al. 2019) and further work in this area is warranted. Current knowledge is thus insufficient for the design of effective and efficient management and conservation interventions at the requisite regional scale. A greater understanding of the spatial extent and use of feeding areas across the region, and linkages between foraging areas and nesting sites, will allow management agencies to identify overlaps between important turtle habitat and anthropogenic impacts (Casale et al. 2012b) and take site-specific measures to address turtle conservation needs (Schofield et al. 2013).

We present the results of a 4-year study tracking green sea turtles $C$. mydas from foraging areas in the United Arab Emirates (UAE) to identify linkages between feeding areas and nesting sites, migration routes and reproductive behaviour patterns, ultimately to inform national and regional management and conservation approaches. The project complements a similar 4-year study (2010-2013) on hawksbill turtles Eretmochelys imbricata (Pilcher et al. 2014a, b) that was used to identify Important Turtle Areas, potential Marine Protected Area boundaries and size, and to delineate regional Ecologically and Biologically Significant Areas (EBSAs) under the auspices of the Convention on Biological Diversity (CBD), amongst many other uses. Our results also enhance our understanding of Important Turtle Areas (ITAs) for green sea turtles in the Arabian region and demonstrate the value of MPAs in protecting important sea turtle habitats. These findings improve baseline knowledge upon which management agencies may better protect sea turtles, advance our understanding of the biology and ecology of green sea turtles and provide a platform for dialogue and collaboration at an international level to protect sea turtles at important reproductive and development life history stages. 


\section{Materials and methods}

Satellite transmitters were deployed on green sea turtles at Bu Tinah (Abu Dhabi) and the Muzahmi sandbank (Ras Al Khaimah) in the United Arab Emirates (UAE), from 2016 to 2019. The shallow seagrass habitat surrounding Bu Tinah and those offshore of the Muzahmi sandbank were identified as key foraging areas for green sea turtles through previous studies (Hasbún et al. 2000; Miller et al. 2004, EAD 2007) and in consultation with local experts. Bu Tinah lies within the Marawah Marine Biosphere Reserve and is located some $80 \mathrm{~km}$ NNW off the mainland coast of the Abu Dhabi mainland, comprising a small, low-lying sandy cluster of islands and shoals surrounded by extensive seagrass pastures. The Muzahmi sandbank marks the seaward boundary of the Khor Muzahmi Marine Protected Area that lies $5 \mathrm{~km}$ south of Ras Al Khaimah and protects valuable wetlands on the landward side while fronting many acres of pristine seagrass pastures (Fig. 1).

\section{Turtle capture and selection}

Field expeditions took place in May and July 2016; April 2017; March 2018, and May 2019, with the intent of encountering turtles several months before peak nesting seasons in Oman and Saudi Arabia. On Bu Tinah the team caught turtles via rodeo captures (Limpus and Reed 1985) in shallow $(<3 \mathrm{~m})$ foraging areas using a small speedboat and a Jet Ski. Captures were biased towards the larger turtles given the intent to track adults in reproductive condition, but not biased by tail length to enable tracking of both male and female sea turtles. At Ras Al Khaimah the team collected turtles from a beach seine (Hasbún et al. 2000), working with local fishermen who use nets $\sim 500-1000 \mathrm{~m}$ in length towed by outboard-equipped boats from $\sim 1 \mathrm{~km}$ offshore onto the beach over shallow seagrass areas. The nets are towed slowly $(<1 \mathrm{~km})$ and the turtles are able to surface and breathe. The beach seine at Ras Al Khaimah was non-selective and all turtles were processed regardless of size. All turtles were measured $( \pm 0.1 \mathrm{~cm})$, and tagged using Monel tags (https:// nationalband.com). Age class (juvenile, sub-adult, adult), reproductive condition and sex were then determined using laparoscopy, and if the turtle was not in reproductive condition, it was released within 30-60 min of capture.

\section{Laparoscopy}

To maximise the potential for identifying connectivity between foraging areas and nesting sites, we sought only turtles that had a high probability of undertaking a breeding migration while the transmitters were active. Using laparoscopy, we used the presence of advanced-stage developing follicles in females and full seminiferous ducts in males, described by Hamann et al. (2003) and Miller and Limpus (2003), as indicative of impending reproduction activity. Laparoscopic procedures mirrored descriptions by Limpus and Read (1985): turtles were placed in dorsal recumbency; an $8-10 \mathrm{~mm}$ incision was made in the inguinal region through which a cannula and trocar were inserted through the muscle tissue and coelomic membrane. A $5 \mathrm{~mm} \times 30 \mathrm{~cm}$ rigid laparoscope was then inserted through the cannula to inspect the gonads. This was invariably completed in 5-10 min, following which the laparoscope was removed, any naturally adsorbed air was removed through careful application of pressure and the incision point was closed with self-dissolving sutures. The incision point was then treated with antibacterial spray and allowed to dry.

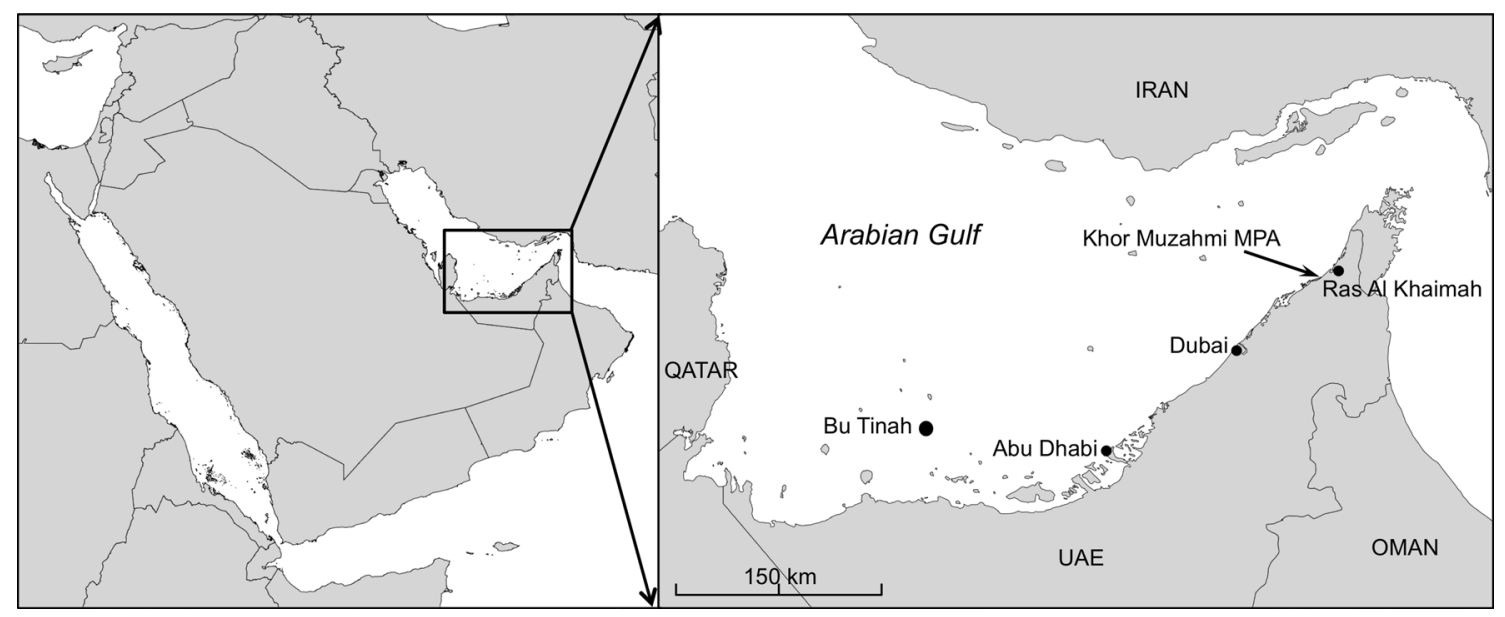

Fig. 1 Locations of Bu Tinah, off Abu Dhabi, and Khor Muzahmi in Ras Al Khaimah, in the United Arab Emirates 


\section{Satellite transmitter attachment protocols}

Satellite transmitters were deployed on adult male and female turtles with the exception of one subadult female turtle at Ras Al Khaimah in 2018. We deployed SPOT-352B transmitters (https://wildlifecomputers.com) on 23 female and nine male turtles and KG376E transmitters (https:// www.sirtrack.co.nz) on nine females and four males. In total, 37 transmitters were deployed at Bu Tinah and eight were deployed at Ras Al Khaimah. Metadata for the satellite-tracked turtles are provided in Supplementary Table 1. Transmitters were attached using a combination of epoxy and fiberglass, and the turtles were released back into the sea after an average of 3 hours.

\section{Data analysis}

Satellite signals were sourced from Argos (http://www.argos .com) and downloaded by the Satellite Tracking and Analysis Tool (Coyne and Godley 2005). Data were filtered as per Pilcher et al. (2014a) to eliminate erroneous location fixes: we filtered for location fix qualities 3, 2, 1, A and $\mathrm{B}$, speeds of $\leq 5 \mathrm{~km} / \mathrm{h}$ between fixes and implausible data such as points on land. We included A and B data because of the low latitude that limits the number of locations via fewer Argos satellite passes (Pilcher et al. 2014a). To accommodate potential differences in day and night behaviour we selected only the location fix of highest value closest to midday and that of highest value closest to midnight. Minimum distances were calculated assuming straight-line movements between the location fixes, taking into account the spherical shape of the planet. Where tracks crossed landmasses, the shortest route around the land mass was extrapolated using straight sectors. Average swim speeds were determined by dividing total displacement by the time interval between start and end points for each migration phase. Proximity of location fixes to the coast was determined using the Nearest Feature function in Cartographica 1.5.1. and water depth was approximated using bathymetric charts. To determine if looping movements were linked to sea surface temperature as was found for hawksbills in the Arabian Gulf by Pilcher et al. (2014b), we acquired sea-surface temperature data via the NOAA OceanWatch-Central Pacific (OWCP) data portal (http://oceanwatch.pifsc.noaa.gov). Finally, we used telemetry data to infer nesting emergences based on the number of 10- to 14-day internesting intervals (Miller 1997) after their arrival at the nesting site and prior to undertaking purposeful post-nesting migrations to their foraging areas.

Location fixes were split into several States and broadly coincident with descriptions in Pilcher et al. (2014a): Foraging behaviour was inferred from short distance movements with random heading changes in the vicinity of the deployment site. Migration behaviour was identified by more directionally uniform movements between location fixes along with greater rates of displacement. These were assessed visually for each turtle. We assumed nesting behaviour had commenced when the migration ended and the turtles again displayed slower, shorter distance movements with random heading changes in the vicinity of the nesting site, similar to movement patterns during foraging. Following a period of 2-3 weeks for mating, ovulation and egg development, each approximate 2-week block following the estimated first nesting event was considered a subsequent nesting event based on known internesting intervals for green turtles. Location fixes following departure from the nesting location were categorised as return migration fixes (direct travel from the nesting site with minimal deviation from a straight path and faster displacement speeds).

To further delineate important foraging areas for green sea turtles, and compare thee with existing MPAs, we computed kernel density estimates (KDE) of home ranges $(90 \%$ density of foraging location fixes) and core areas (50\% of foraging location fixes) using only the foraging area location fixes in ArcGIS 10.1 (Gaussian kernel; bandwidth =8; $K=3$ ). Turtle size data were tested for normal distributions using a Kolmogorov-Smirnov Test of Normality and ANOVA tests were used on normally distributed data sets using StatPlus 5.8.

\section{Results}

\section{Size, age class and breeding condition}

We captured 233 turtles and selected 44 adults in breeding condition and one sub-adult female on which to deploy satellite transmitters. With the exception of seven turtles we recorded age class, sex and sizes of all turtles we encountered (summarised in Table 1). Of those turtles for which sex and age class data were available, a total of 11 males (23\% of adult males) and 33 females (26\% of adult females) were in breeding condition (Fig. 2; Table 2). Female turtles in breeding condition represented an average of $24 \%$ (range $10-33 \%$ ) of the total adult females captured between 2016 and 2019, while the males in breeding condition represented $23.4 \%$ of the total adult males captured (range 12.5-40\%).

Data for adult male and female curved carapace length (CCL) were normally distributed in both males $(D=0.134$, $P=0.334)$ and females $(D=0.050, P=0.894)$. There was a significant difference $\left(F_{1,177}=27.31, p<0.001\right)$ in CCL between adult male and female turtles, with males being an average of $\sim 5 \mathrm{~cm}$ smaller than females. There were no statistical differences between sizes of males and females in juvenile and subadult size classes. There were also no significant differences between sizes of all 
Table 1 Summary of curved carapace length (CCL) for different age classes and sex groups among green turtles from Bu Tinah and Ras Al Khaimah

\begin{tabular}{|c|c|c|c|c|c|c|c|c|}
\hline & \multicolumn{2}{|c|}{ Juvenile } & \multicolumn{2}{|c|}{ Subadult } & \multicolumn{2}{|l|}{ Adult } & \multicolumn{2}{|c|}{ Tracked } \\
\hline & Male & Female & Male & Female & Male & Female & Male & Female \\
\hline Average & 59.08 & 55.20 & 79.81 & 83.27 & 91.65 & 96.89 & 89.18 & 96.82 \\
\hline SD & 10.532 & 13.052 & 8.645 & 11.908 & 4.779 & 6.218 & 4.266 & 5.397 \\
\hline Min & 46.6 & 33.4 & 65.3 & 62.9 & 82.4 & 72.5 & 82.4 & 85.3 \\
\hline Max & 75.8 & 76.75 & 90.9 & 101.5 & 106 & 110.2 & 98 & 110.2 \\
\hline$n$ & 6 & 11 & 14 & 30 & 47 & 126 & 13 & 32 \\
\hline
\end{tabular}

The tracked turtles are a subset of all of the adult turtles
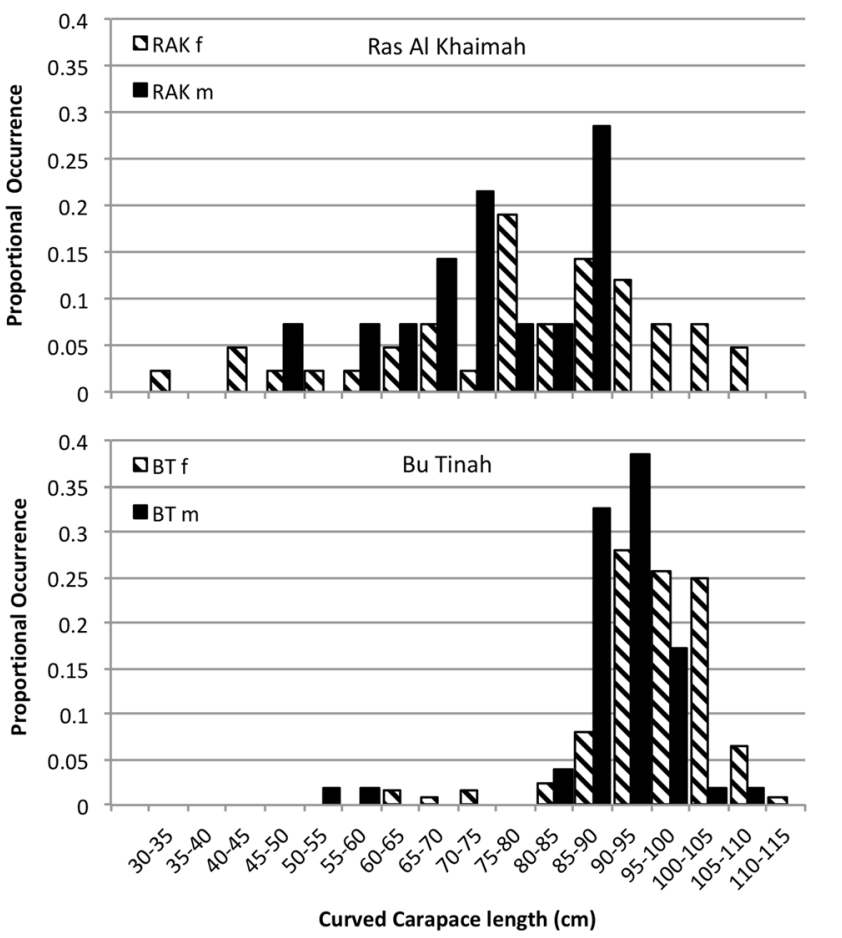

Fig. 2 Size - frequency distribution of sea turtles by sex. Upper panel: Ras Al Khaimah. Lower panel: Bu Tinah. Solid bars: male. Diagonal lines: female

adult females and those that we tracked $\left(F_{1,156}=0.002\right.$, $p=0.96)$. Tracked male turtles were slightly smaller than the mean of all males captured, but this was not significant $\left(F_{1,58}=2.82, p=0.10\right)$. The sizes of adult female turtles (average $=96.9$ ) were consistent with previous findings in the Arabian region (98.0, Miller 1989; 98.2, Al-Merghani et al. 2000; 92.8 (median), Hasbún et al. 2000). There are no previously reported data for male turtles.

On $\mathrm{Bu}$ Tinah we targeted larger turtles on the foraging areas as our objective was to track adults in breeding condition. Smaller turtles were generally avoided during rodeo captures, and thus the age class structure for turtles encountered by the project is biased toward the larger turtles. At Ras Al Khaimah, the team sampled turtles entrained in the seine net regardless of size; therefore, there was a greater proportion of juvenile and subadult turtles from this location (Table 3). Notwithstanding the bias in captures at Bu Tinah, both foraging areas supported substantially larger proportions of subadult and adult turtles and very few juveniles, most of which were large in size (juvenile CCL: $\bar{x}=56.7$, $n=17$ ), with only one turtle $<40 \mathrm{~cm}$ CCL, captured at Ras Al Khaimah.

\section{Tracking data}

The project acquired 23,127 location fixes over 4,855 tracking days tracking 13 adult male turtles, 31 adult females and one subadult female. We used 7508 filtered location fixes for the movement analysis by using the highest quality day and night location fixes, noting that not all turtles relayed location data every day.

Activity States were assigned to each turtle by identifying start and end dates of short, random heading movements and longer, uniform heading movements. Given inferences on behaviour were made from track orientation and swim speeds, we computed travel speeds for all movements within foraging areas $\left(\bar{x}=0.34 \mathrm{~km} \mathrm{~h}^{-1}, \mathrm{SD}=0.182\right.$, range $\left.0.06-1.04 \mathrm{~km} \mathrm{~h}^{-1}, n=56\right)$ and compared these to travel speeds during migrations $(\bar{x}=0.779, \mathrm{SD}=0.413$, range
Table 2 Annual rates of breeding readiness for male and female turtles in the UAE, 2016-2019

\begin{tabular}{lllllll}
\hline & Adult males & Breeding males (\%) & Adult females & \multicolumn{2}{c}{$\begin{array}{l}\text { Breeding } \\
\text { females (\%) }\end{array}$} \\
\hline 2016 & 8 & 1 & 12.5 & 36 & 12 & 33.3 \\
2017 & 10 & 4 & 40.0 & 28 & 7 & 25.0 \\
2018 & 15 & 3 & 20.0 & 32 & 8 & 25.0 \\
2019 & 14 & 3 & 21.4 & 29 & 3 & 10.3 \\
\hline
\end{tabular}


Table 3 Proportional contributions of sex and age classes to the foraging green turtle populations at $\mathrm{Bu}$ Tinah and Ras $\mathrm{Al}$ Khaimah

\begin{tabular}{|c|c|c|c|c|c|}
\hline \multicolumn{6}{|c|}{ Bu Tinah } \\
\hline \multicolumn{2}{|c|}{ Juvenile } & \multicolumn{2}{|c|}{ Subadult } & \multicolumn{2}{|l|}{ Adult } \\
\hline $0^{\lambda}$ & 우 & $\hat{\sigma}$ & 우 & $\hat{\sigma}$ & 우 \\
\hline $1.1 \%$ & $0.6 \%$ & $5.1 \%$ & $9.0 \%$ & $23.7 \%$ & $60.5 \%$ \\
\hline \multicolumn{6}{|c|}{ Ras Al Khaimah } \\
\hline $7.1 \%$ & $17.9 \%$ & $8.9 \%$ & $25.0 \%$ & $8.9 \%$ & $32.1 \%$ \\
\hline
\end{tabular}

$\left.0.05-2.18 \mathrm{~km} \mathrm{~h}^{-1}, n=39\right)$. There was a significant difference in travel speeds (nearly double) between the short, random heading movements detected at foraging areas when compared to more direct and faster movements during migrations $\left(F_{1,93}=49.35, p<0001\right)$, affirming our State differentiation protocols. The overall breakdown of activity patterns among turtles was as follows:

- Nine turtles undertook nesting migrations towards Ras al Hadd in Oman (eight females and one male). Of these, three completed nesting and returned to Bu Tinah $(169,438,170,124$ and 170,125; see Pilcher et al. 2020 for details); one completed nesting and commenced a return migration prior to signal loss $(169,437)$; two commenced nesting but signals were lost prior to the end of the nesting season $(169,439$ and 170,131); and two turtles followed the same outbound movements but signals were lost close to Ras Al Khaimah (160,240 and $169,432)$. The male turtle $(169,433)$ moved towards Ras al Hadd but signals were lost close to the Daymaniyat islands NW of Muscat (Fig. 3). The male turtle was the only turtle to remain in coastal waters during the entire migration, tracking along the eastern coast of Oman and the UAE. The Oman site was the only nesting destination recorded during the project;

- Six turtles (one male and five females) undertook looping movements to the NNE into deeper waters of the Arabian Gulf before returning to take up residence at $\mathrm{Bu}$ Tinah $(169,443,169,445$, and 170,126$)$ or alternate foraging areas $(160,243$ and160245). One turtle $(170,121)$ was still moving when the signals ended (Fig. 4). Loops lasted 21-491 days and none had any pauses that would have suggested breeding or foraging along the way. Sea surface temperatures at the temporal mid-point during the looping movements were an average of $0.3{ }^{\circ} \mathrm{C}$ cooler than at origin prior to departure $(\mathrm{SD}=0.68$, range - 0.69-1.08), and $0.5{ }^{\circ} \mathrm{C}$ cooler than $\mathrm{Bu}$ Tinah on their return $(\mathrm{SD}=0.34$, range $0.16-0.89)$. Neither of these differences were significant $(P=0.06$ and $P=0.36$, respectively);

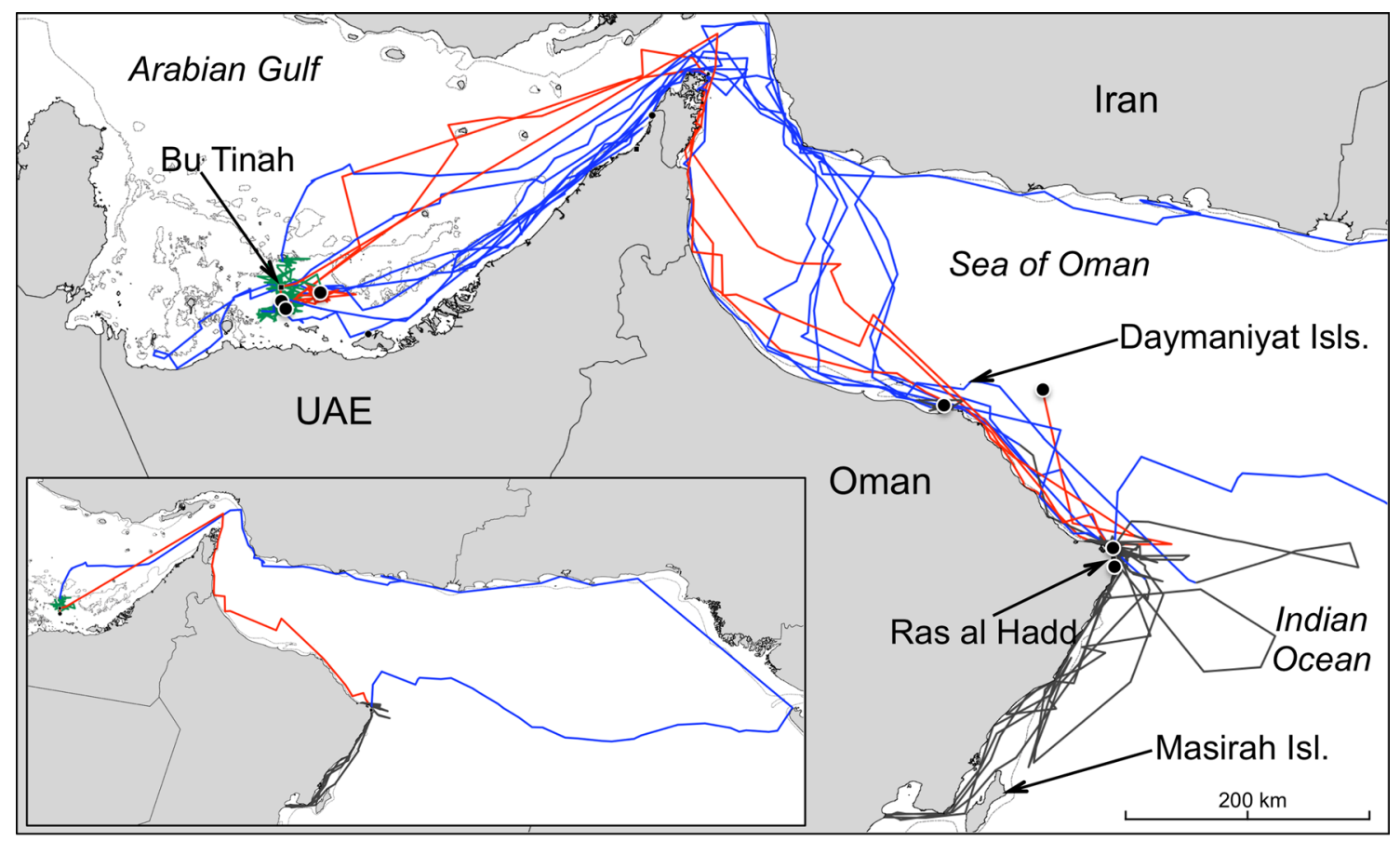

Fig. 3 Migrations linking the $\mathrm{Bu}$ Tinah foraging area in the UAE and the nesting site at Ras al Hadd in Oman. Inset map shows the full extent of the outbound migration by turtle 170,124. Colour lines represent activity states: foraging (green); migration (blue); internest- ing (grey) and return migrations (red). Male turtle track ended by the Daymaniyat Islands and remained coastal throughout the journey. End locations shown by black circles. Thin grey line is the $20-\mathrm{m}$ bathymetric contour 


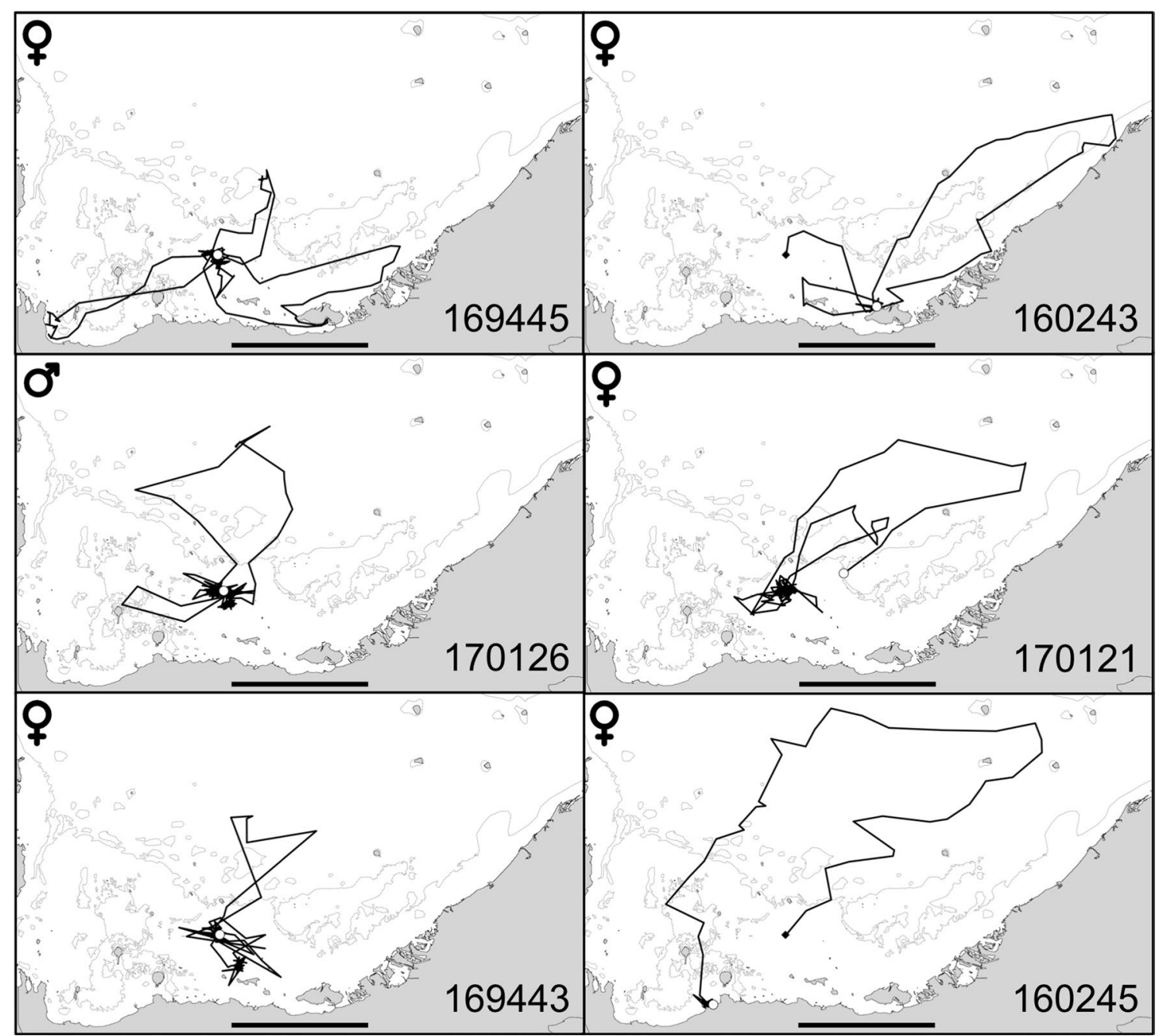

Fig. 4 Looping movements of five female turtles and one male turtle that undertook looping movements into the Arabian Gulf and returned to foraging areas. Left-side images all returned to Bu Tinah

- Only two female turtles made substantive movements from Ras Al Khaimah: one female $(160,239)$ headed SW to an area off Saadiyat Island (Abu Dhabi Emirate), where she remained for 259 days before returning to the Ras Al Khaimah foraging area for an additional 26 days prior to signal loss. Due to similarities in movement patterns for foraging and internesting turtles (short, random heading movements) it is unknown if this was a movement related to reproduction or simply the use of an alternate foraging area; however, Saadiyat is not known as a green turtle nesting site. A second female $(170,122)$ moved SW to the Abu Dhabi emirate, but signals were lost before she settled at a foraging area (Fig. 5).

- Two male turtles made substantive movements off $\mathrm{Bu}$ Tinah: One turtle $(169,436)$ migrated NE along the UAE coast, reversed course at Ras Al Khaimah to the SW to a location $20 \mathrm{~km}$ off the coast of the UAE between Dubai (departure point). Right-side images returned to alternate foraging sites. White open circles denote end points. Black bar represents $100 \mathrm{~km}$

and Sharjah. He remained there for a month before heading NE once again to Musandam before reversing course and spending another month at the same place between Dubai and Sharjah, prior to returning to Bu Tinah. Given that he was assessed to be in breeding condition, this movement pattern may be associated with mating behaviour which, of note, occurred $250 \mathrm{~km}$ from the foraging area and $\sim 800 \mathrm{~km}$ from the nesting site. A second male turtle $(169,440)$ remained at $\mathrm{Bu}$ Tinah for 112 days before heading NW towards Qatar, where signals ended. Salt-water switch sensor data suggest this turtle was drifting on the surface for several days prior to signal loss, and combined with the close spacing of data points in the last days of the track, this suggests the turtle had died and was floating (Fig. 6);

- Nine additional turtles moved off Bu Tinah but the movements were of insufficient duration to be conclusive. It is 


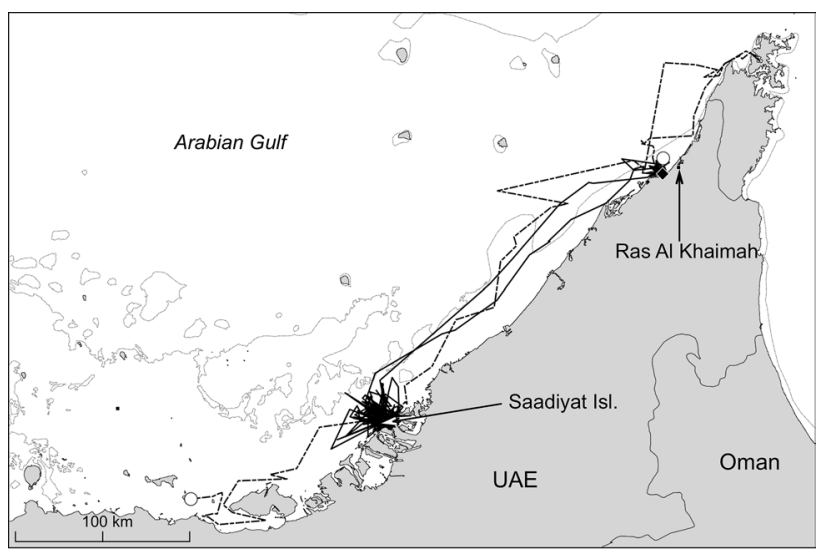

Fig. 5 Movements of two female turtles from Ras Al Khaimah: 160,239 (solid line) moved SW to Saadiyat Island, remained there for 259 days and returned to Ras Al Khaimah. 170,122 (dashed line) also travelled SW but signals were lost in western Abu Dhabi. End points depicted by white circles. Grey lines: $20 \mathrm{~m}$ bathymetric contours

possible some of these were commencing nesting migrations (particularly 160,228 and 160,241) or commencing looping movements but signals ended before we could determine any of these (Supplementary Fig. 1).
- A final 17 turtles (including the single sub-adult turtle) remained on or near the foraging areas with signal duration ranging from 5 to 252 days $(\bar{x}=71.9)$. Among these, signal duration was significantly shorter for 14 units that were deployed prior to 2018: $\bar{x}=59.0$ (5-252 days), compared to $\bar{x}=127.7$ ( $81-211$ days) for the only three units deployed in 2018 and 2019 that remained on the foraging areas.

Importantly, nine of 23 turtles (39\%) that undertook substantial movements off the UAE foraging areas headed towards the Ras al Hadd nesting area in Oman or followed similar movement patterns before signal loss. Only one turtle, a male, headed NW towards Qatar, possibly towards the Saudi Arabia breeding areas, but signals were lost as the turtle reached NE Qatar. These data point to a distinct connectivity between the UAE and Ras al Hadd for adult green sea turtles, and a lack of connectivity with the (closer) nesting islands off Saudi Arabia to the north. In 2016 and 2017 the project experienced poor transmitter retention rates and short transmitter signal durations and we believe this was largely related to the quality of the epoxy glues used during attachment, although there were also several unexplained signal losses when salt-water switch data were examined.

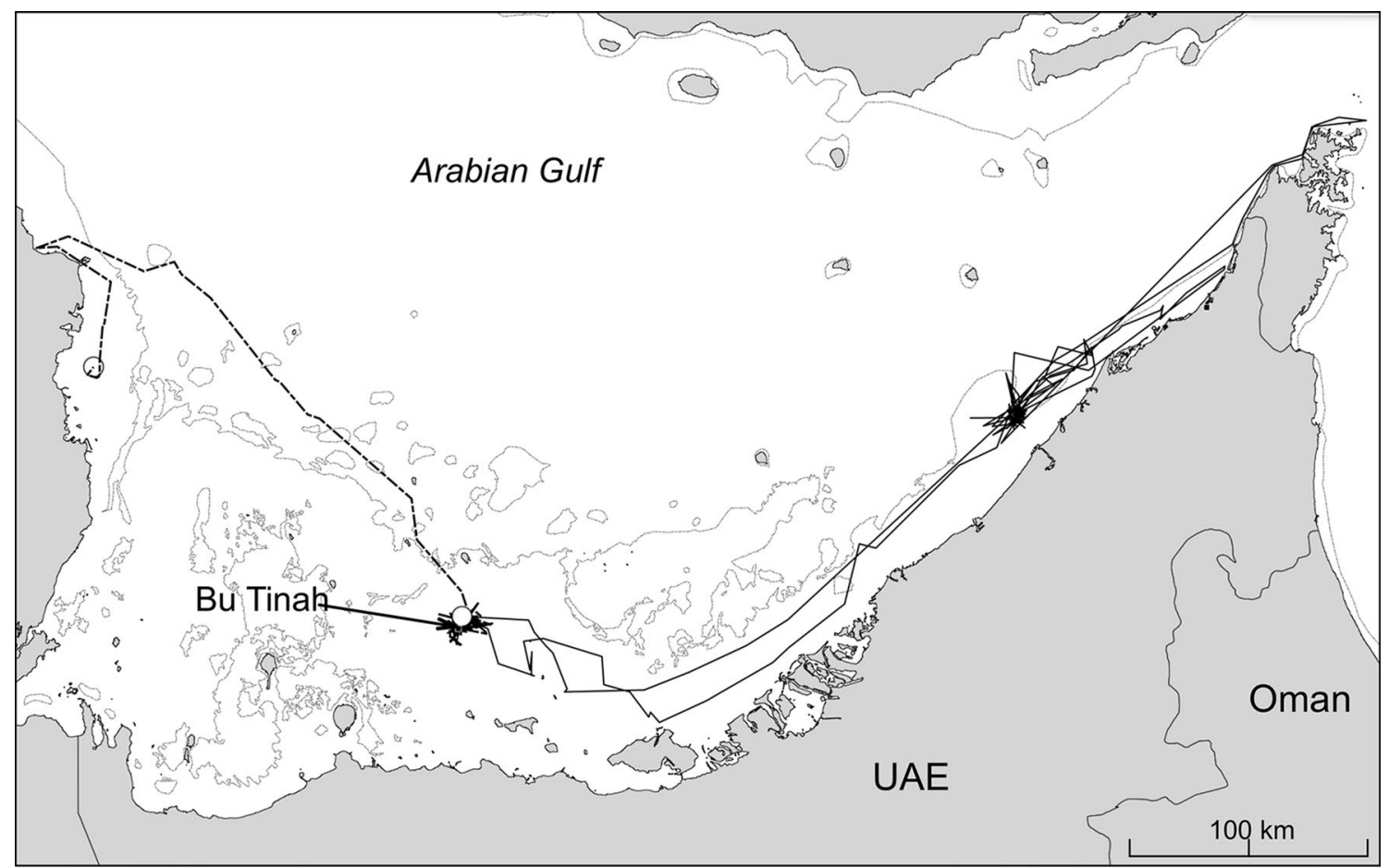

Fig. 6 Movements of two male turtles from Bu Tinah: 169,436 (solid line) made several forays to the NE of the United Arab Emirates and returned to $\mathrm{Bu}$ Tinah - possibly indicating the location of mating areas; 169,440 (dashed line) departed to the NW and signals were lost as it tracked slowly and on the surface southward after reaching northern Qatar. End points depicted by white circles. Grey lines: $20 \mathrm{~m}$ bathymetric contour 


\section{Core Foraging areas-Ras AI Khaimah emirate}

Key foraging areas were detected immediately off the Muzahmi sandbank where tags were deployed, with some foraging also occurring SW in the Emirate of Umm Al Quwain. In total, the project logged 868 days of foraging area locations from which $50 \%$ home range and $90 \%$ core area KDEs were derived. The bulk of the location fixes were in the area immediately offshore of the Muzahmi sandbank where the transmitters were deployed, extending $\sim 5 \mathrm{~km}$ offshore, and $\sim 10 \mathrm{~km} \mathrm{SW}$ to NE. The home range extended over $46 \mathrm{~km}^{2}$ while the two small core areas measured a combined area of $\sim 8 \mathrm{~km}^{2}$.

\section{Core Foraging areas_Abu Dhabi emirate}

A combined total of 4622 foraging area location fixes were recorded over 2601 days among 35 turtles in the SW Arabian Gulf waters off the Abu Dhabi Emirate, where two Marine Protected Areas have been established - the Marawah Marine Biosphere Reserve in which Bu Tinah is located, and $\mathrm{Al}$ Yasat Marine Protected Area. There were virtually no location fixes (only five of all filtered data points) recorded in the $\mathrm{Al}$ Yasat marine protected area, while the vast majority $(84.4 \%)$ of foraging location fixes in the SW Arabian Gulf were located within the Marawah Marine Biosphere Reserve boundaries (Fig. 7).

\section{Discussion}

The location data we present herein have revealed previously unknown details about green sea turtle biology and ecology in the Arabian region. We have determined that the primary nesting destination for turtles from $\mathrm{Bu}$ Tinah in the UAE is Ras al Hadd in Oman. While moving from $\mathrm{Bu}$ Tinah the turtles generally stay some $20 \mathrm{~km}$ off the coast, in waters $10-20 \mathrm{~m}$ deep. While migration routes are not copied exactly, the general movement pattern is consistent. The turtles use the waters of the UAE, Iran and Oman during the breeding migrations and return migrations are generally far more direct than outbound migrations. The turtles display considerable fidelity to the original foraging sites, often traversing other known foraging sites when returning from the breeding migration. However, a small proportion of turtles were also recorded utilising more than one foraging site. We have also determined that the extent of the marine protected area in Abu Dhabi is broadly coincident with the foraging areas of turtles offering substantial protection from fishery activities but that the newly declared protected area in Ras Al Khaimah would be more effective in protecting green sea turtles if it extended $\sim 5 \mathrm{~km}$ offshore and $\sim 10 \mathrm{~km}$ up and down the coast.

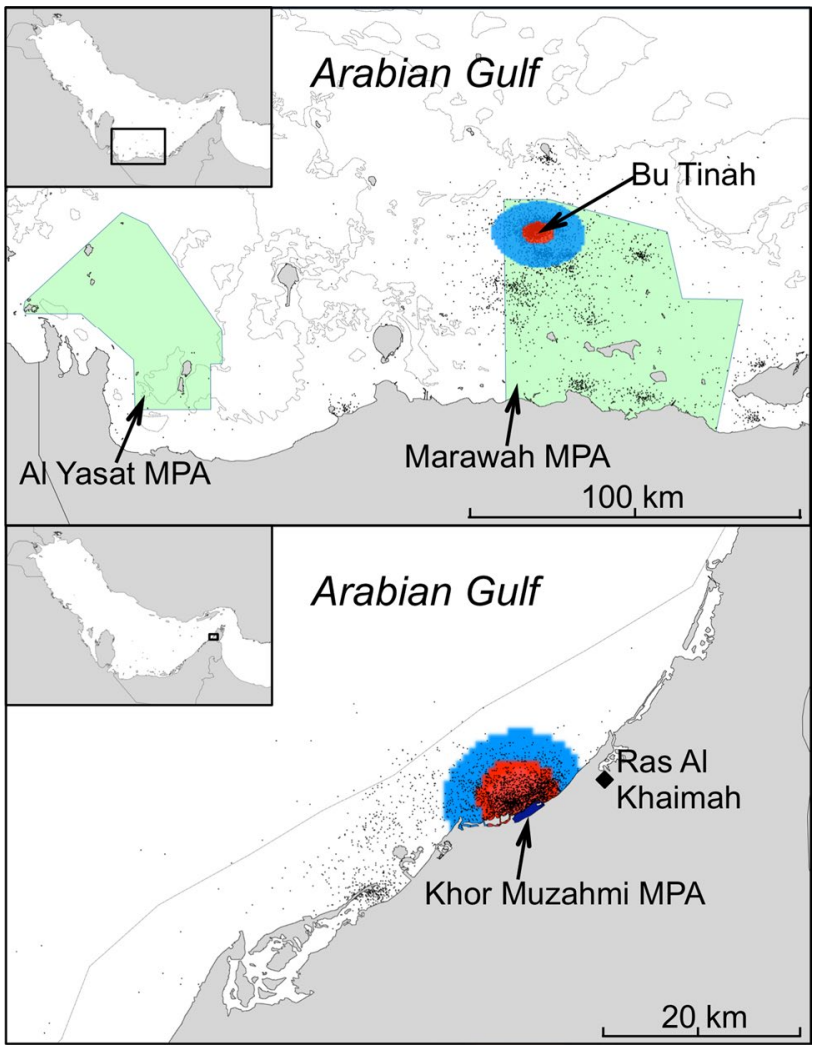

Fig. 7 Kernel Density Estimation (KDE) depicting 50\% core areas (red) and $90 \%$ home range (light blue) of key foraging area in the vicinity of and $\mathrm{Bu}$ Tinah (top) and Ras Al Khaimah (bottom). Black dots are foraging area location fixes; $20 \mathrm{~m}$ depth contours are shown in light grey; green polygons represent the two Marine Protected Areas in Abu Dhabi and the dark blue polygon is the Khor Muzahmi MPA in Ras Al Khaimah

\section{Habitat connectivity}

Our data point to distinct habitat connectivity between foraging areas in the United Arab Emirates and nesting sites in Oman. Details of three of round-trip tracks are provided further described by Pilcher et al. (2020). The connection to Oman is unsurprising given the size of the annual nesting populations of $\sim 5000$ female green turtles (Mancini et al. 2019). The lack of turtle migration towards nesting sites in Saudi Arabia to the NNW-with the exception of the inconclusive male turtle movement in 2019—suggests there is less frequent movement between UAE foraging areas and Saudi Arabian nesting beaches. This is potentially explained by the size of the Oman nesting stack, which is some five times greater than that of Saudi Arabia (Mancini et al. 2019). There could be a proportion of UAE turtles that do move to Saudi Arabia, but this was not demonstrated by our work, possibly due to sample size and the dearth of movements in 2016 and 2017. Recent tracking of post-nesting females from Saudi Arabia noted that turtles moved broadly towards the 
north and the east of the Gulf (Maneja et al. 2018), although one of their turtles did move south to an area close to $\mathrm{Bu}$ Tinah. Further sampling in the UAE may reveal some level of movement to the Saudi Arabian nesting sites, but we suggest this will be a fraction of those turtles moving to Oman. This dependence on Oman as a nesting destination raises the importance of that nesting site for the conservation of sea turtles in the UAE, and across the greater NWIO.

\section{Breeding biology}

Adult sea turtles spend several years at foraging areas assimilating energy supplies to enable breeding migrations, whereupon they depart to distant nesting. Not all turtles breed every year (Hepell et al. 2003), and the proportion of sea turtles at a nesting site is determined via the proportion of turtles undergoing vitellogenesis and spermatogenesis on the foraging areas in the months prior to nesting, which is governed by ambient conditions (Limpus and Nicholls 1988; Solow et al. 2002; Saba et al. 2007) and food availability (Chaloupka and Limpus 2001; Alerstam et al. 2003) in the years preceding nesting. Predicting breeder abundance at a nesting site can help maximise monitoring efficiency and plan for efficient resource deployment (e.g., Saba et al. 2007; Chevallier et al. 2020). These predictions require long-term capture-mark-recapture records and extensive modelling of nesting beach data (and this is only possible for female turtles), or identification of breeding condition of sea turtles on foraging areas prior to the nesting season, such as that derived from laparoscopy. Our study identified that an average of $\sim 25 \%$ of adult turtles were in breeding condition each year between 2016 and 2019, slightly higher than results for green turtles on an Australian foraging area (the only other place where this is known), which ranged from $0.08 \%$ to $35.1 \%$ of all adult female turtles sampled each year between 1986 and $2004(x=12 \%)$, and $\bar{x}=34 \%$, (range 0-77\%) in male turtles (Limpus et al. 2005). We suggest differences between our findings and the more robust and longer-term data from Australia are influenced by (1) our smaller sample sizes and shorter study duration, and (2) that the warmer annual climate in the Arabian Gulf (Pilcher et al. 2014b) may promote higher rates of nutrient assimilation and higher annual breeder readiness (Southwood Williard 2007). These are the first data on proportion of adult green turtles in breeding condition from Arabian region foraging areas. We suggest that long-term in-water monitoring programmes to investigate age class, sex ratios and breeder readiness at $\mathrm{Bu}$ Tinah and Ras Al Khaimah could provide an annual index of this important population dynamics metric.

\section{Fidelity to foraging areas}

Sea turtles also demonstrate high degrees of fidelity to foraging areas that they have used in the past (Broderick et al. 2007; Limpus 2009; Schofield et al. 2010) and our findings support similar conclusions for the Arabian region (seven of the nine turtles tracked back to foraging areas returned home). There were some exceptions to this pattern and it is likely a small proportion of UAE sea turtles use multiple foraging areas as detected by Shimada et al. (2020), or may not leave the foraging area at all (in the case of male turtles). Acknowledging the limits of inferring behaviour through low-resolution Argos-derived tracking data and linking these with general geographical location, it is possible that (a) sea turtles may use multiple foraging areas with negligible loss of foraging efficiency (e.g., Shimada et al. 2020); (b) foraging habitat home range for some green turtles in the Arabian Gulf may be large with several frequently used core areas; (c) that turtles may use different foraging areas in different seasons (e.g., Mingozzi et al. 2016) and (d) that the turtles were not necessarily displacing to those areas where they were tracked for foraging activities. Additionally, male sea turtles may reside permanently on the same foraging areas once they attain adulthood. Recent observations of mounted pairs of green sea turtles at $\mathrm{Bu}$ Tinah (EAD unpublished data) indicate that some mating occurs at the foraging areas, following which (presumably) the male turtles do not depart. It is likely that this accounts for the behaviour of at least five of the ten male turtles tagged at Bu Tinah, particularly as three of these provided signals for substantial periods (73, 211 and 523 days). These findings for male turtles are preliminary, and further investigation into this phenomenon is warranted.

\section{Looping movements}

Several turtles departed Bu Tinah on looping movements, with four of these returning to Bu Tinah and one of them taking up residence at a location $\sim 80 \mathrm{~km} \mathrm{SSW}$. Pilcher et al. (2014b) detected looping summer loop movements by hawksbill turtles in the Arabian Gulf and determined that these were a behavioural adaptation to high sea surface temperatures (SST), with the turtles moving off established foraging areas in July and August and returning in September and October after a lengthy pause in deeper, $2{ }^{\circ} \mathrm{C}$ cooler waters to the northeast. The green turtles that undertook the loops during this study differed in that (a) they did not pause during these substantially shorter looping movements, all of which were completed in shorter periods (10-31 days, $\bar{x}=17.0$ ); (b) the timing of departure and return to the foraging areas generally occurred after mid-August with most returns in late-August to mid-September before waters had cooled significantly at Bu Tinah; and (c) the direction of 
movement was inconsistent with some migrations to the west and to the east, and not necessarily into deeper and cooler waters of the Gulf. Average latitudinal displacement (91.5 km northward) was similar to hawksbill turtle movements and is likely reflective of the confined nature of the Arabian Gulf. SST values at the mid-points in the loops was an average of $0.3{ }^{\circ} \mathrm{C}$ cooler than at the point of origin prior to departure and an average of $0.5{ }^{\circ} \mathrm{C}$ cooler than at their return. These differences were not significant and occurred in only seven of 20 turtles that remained at $\mathrm{Bu}$ Tinah, but we believe there exists the possibility that green turtles may also exhibit some form of behaviour to avoid warmer waters in the climate-challenged Arabian region (see Pilcher 2014b; Pilcher et al. 2015).

\section{Foraging area differentiation}

Finally, sea turtles undergo ontogenetic shifts in location and habitat as they grow (Heppell et al. 2003), and our data suggest that the Ras $\mathrm{Al}$ Khaimah and $\mathrm{Bu}$ Tinah foraging areas are secondary foraging / developmental habitats for green sea turtles in the Arabian Gulf, given the predominance of large adults and sub-adults in our samples, and the virtual absence of small juveniles (only one turtle $<50 \mathrm{~cm}$ CCL was collected during this project). In comparison, foraging areas off the coast of Qatar just $150-200 \mathrm{~km}$ to the NW of Bu Tinah hosted primarily small ( $<50 \mathrm{~cm}$ CCL) juveniles (Pilcher et al. 2015), and juveniles comprised $96.4 \%$ of all turtles in foraging areas off the coast of Qeshm in Iran, $100 \mathrm{~km}$ N of Ras Al Khaimah, and averaged $42.7 \mathrm{~cm} \mathrm{CCL}$ (N. Pilcher unpublished data). Similarly, Khor Kalba in the Emirate of Sharjah, fronting the Gulf of Oman, is home to only juvenile green turtles (Hebbelman et al. 2016). This suggests there are distinct foraging areas in the Arabian Gulf region for smaller turtles that recruit to adult-predominant foraging areas in later years. The fact that these UAE foraging areas are home to the older age-classes of NWIO sea turtles and that these turtles have the greatest biological value (Crouse et al. 1987) points to a need for targeted conservation and protection of these key habitats.

Our data indicate that the home ranges of foraging green sea turtles are broadly coincident with the Marawah Marine Biosphere Reserve (84.4\% of location fixes were located within the Reserve boundaries), but that there was little protection afforded to foraging sea turtles off Ras Al Khaimah and Umm Al Quwain, where the one protected area lies to the $\mathrm{SE}$ of the primary home range KDE for foraging green turtles. It is not a coincidence that the Marawah Marine Biosphere Reserve and green turtle foraging areas broadly overlap, as the Reserve was primarily established to protect the world's second largest population of dugongs (Dugong dugon), another large marine herbivore sharing a similar diet to that of the green turtle. The large overlap between foraging areas and an established MPA in Abu Dhabi also further support the compelling findings by Scott et al. (2012) of the overlap between turtle distribution worldwide and MPA boundaries, and the importance MPAs and their management bring to sea turtle conservation.

While our data did not indicate movements of turtles to other potential green turtle habitat in western Abu Dhabi and the Al Yasat Marine Protected Area, it is likely that this simply reflects the low incidence of multiple foraging habitat use, and it is likely that these waters are also home to substantial numbers of sea turtles, warranting further investigation. While recent work has highlighted the importance of Khor Muzahmi, as it hosts a mosaic of different habitats such as seagrass, mudflats and mangroves supporting rich biodiversity (Lamine et al. 2020), and the Bu Tinah foraging area has been well studied (EAD 2007), we recorded a number of foraging areas outside of the protected areas which also warrant further investigation and some degree of management, as these are obviously also of importance to sea turtles. Consistent with the recommendations from our previous study on hawksbill sea turtles (Pilcher et al. 2014a), granting formal recognition to these key foraging areas as Important Turtle Areas (ITAs) would provide support for additional protection or conservation efforts and possible extension of the protected area. International policy instruments, such as the Ramsar Sites of International Importance (Ramsar 2018), could also help accelerate such efforts.

\section{Challenges to tracking turtles from foraging areas}

The combination of laparoscopy with satellite tracking to track reproductive adult turtles from foraging areas faces two key challenges: determination of vitellogenic/spermatogenic stage, and transmitter retention. We acknowledge that we faced these challenges in this project, but suggest with some refinement that this is an extremely valuable research application. Several team members visually confirmed gonadal condition in nearly all cases, and we are confident that the presence of full seminiferous ducts and developing follicles were accurately identified. However, as noted by Pilcher et al. (2020), "given the potentially long period of vitellogenesis (up to 10-12 months; Miller 1997) there is the possibility that (a) the vitellogenic process was accurately identified but that transmitter loss occurred before turtle departure, (b) full seminiferous ducts in males were a remnant of past breeding rather than an indication of upcoming breeding, or (c) that male turtles may mate at the foraging areas and not depart". Recent observations of mounted pairs of green sea turtles at $\mathrm{Bu}$ Tinah (EAD unpublished data) support this notion.

The loss of transmissions from satellite transmitters for unknown reasons is a pervasive problem across many tracking studies (Hays et al. 2007). Despite the number of units 
deployed in this study, few provided signals that were of sufficient duration to conclusively interpret the movement behaviour. We acknowledge that in 2016 and 2017 the tag retention rate was low and believe this was linked to the quality of the epoxy glue used in the attachment process. We also introduced multiple layers of antifouling paint following the poor signal acquisition in year 1 and ensured that the carapace was thoroughly cleaned using several applications of acetone. We believe these additional steps also contributed to improved results in the second half of the project. Our interpretation of movements was further limited by the looping movements of turtles that departed the foraging areas and then returned, having not reached any nesting destination. It has been suggested that the capture, processing and attachment of transmitter may impact depart timing, disrupt foraging behaviour, induce longer internesting periods and alter diving behavior in leatherback turtles (Wallace et al. 2005; Sherrill-Mix and James 2008). We acknowledge the possibility of impacts to turtles in this study, but note that of the five turtles that undertook looping movements, four remained on the foraging area for an average of 172 days ( $\mathrm{SD}=85.2$, range 111-295). Only one departed immediately, and this occurred in only four of the 44 turtles we tracked. All of the turtles tracked in this study were large $(>82 \mathrm{~cm}$ CCL) and we do not believe the transmitter itself may have caused substantial drag, as has been found for smaller turtles (Watson and Granger 1998).

\section{Conservation and management}

It is evident that Ras al Hadd in Oman is the primary nesting destination for green sea turtles from the United Arab Emirates, and this can be used to initiate bilateral approaches to conservation. While linkages to Saudi Arabian nesting sites have not been documented as yet, this may be reflective of insufficient tracking data. Sea turtles also migrate through sovereign waters of Iran, and in rare cases also Pakistan and India, highlighting the wider international dimension of sea turtle biology and life cycles. Our results confirm connectivity across different countries and demonstrate the need for regional collaboration to effectively conserve shared populations. Regional dialogue and collaboration can be facilitated through international conventions, such as the Convention of Migratory Species (CMS) and its regional Memorandum of Understanding on the Conservation and Management of Marine Turtles and their Habitats of the Indian Ocean and South-East Asia (IOSEA MoU).

UAE sea turtles demonstrate fidelity to specific seagrass habitats, which are secondary foraging areas for Arabian sea turtles that host primarily older and biologically valuable sea turtles, and their protection can be enhanced by strict enforcement of fishery regulations in existing MPAs, expansion of the MPA off Ras Al Khaimah and identification of additional important turtle habitats in western Abu Dhabi. The Marawah Marine Biosphere Reserve protects over $80 \%$ of key foraging areas for $\mathrm{Bu}$ Tinah turtles, and the $\mathrm{Al}$ Yasat MPA likely protects stocks of turtles resident in western Abu Dhabi. Migration movements were often through waters within 10-20 km of the coast of the UAE and Oman, where turtles may be susceptible to human activities such as fishing and boat traffic in these areas. Spatial overlays of the results of our study with coastal activities can be used to identify possible hotspots where management measures to reduce risks of accidental captures in fishing nets or boat strikes may be required. These hotspot analyses can be used to facilitate cross-sectoral dialogue to address anthropogenic impacts on the shared sea turtle populations in the Arabian region.

A substantial proportion $(\sim 25 \%)$ of adult turtles are ready to breed each year, which reflects high seagrass productivity and a healthy reproductive rate. Our data present a suite of new findings to support conservation and management initiatives in the Arabian region, and these combined data contribute significantly to our understanding of green sea turtle biology and ecology in the Arabian climate-challenged environment.

\section{Availability of data and material}

The datasets generated during and/or analysed during the current study are available from the corresponding author on reasonable request. Satellite tracks are made public via OBIS Seamap (http://seamap.env.duke.edu) and the SWOT Global Sea Turtle Tracking Initiative. (https://www.seatu rtlestatus.org).

Acknowledgements We are grateful to H.E. Razan Khalifa Al Mubarak, Managing Director of the Environment Agency Abu Dhabi and Treasurer of the Board at Emirates Nature-WWF and the Board of Directors for their continued support for this project, particularly through the challenging tag-retention period in the first years of the project. We are thankful to the Secretary General of the Environment Agency Abu Dhabi, Dr Shaikha Al Dhaheri, and to her team Ahmed Esmaeil Al Hashmi, Hind Al Ameri, Maitha Al Hameli at the Terrestrial, Marine Biodiversity Division for supporting this effort. We are also extremely grateful to the rangers and support teams on Bu Tinah Island: Hader Al Muheirbi, Mohamed Al Ali, Winston Cowie, Carmen Pilcher, Mona Moller, Manya Russo, Hamad Al Jilani, and Oliver Kerr. We are extremely grateful to the staff and volunteers at the Ras Al Khaimah Environment Protection, Development Authority, including Said Alshehhi, Khalid Mahmood, Essa Alboloshi, Adnan Almansoori, Ibrahem Mustafa, Khalial Ahmed, Ian Carless, James Groves, and Agnes Estay. We are also thankful for tag data interpretation provided by Kevin Lay at Wildlife Computers. This manuscript is dedicated to the memory and legacy of Edwin Mark Grandcourt. We are grateful to two anonymous reviewers who significantly improved this manuscript.

Funding Seed funding for this work was provided by Emirates NatureWWF office in the United Arab Emirates and subsequent funding was 
provided by the numerous sponsors via turtle adoptions and support for the Emirates Nature-WWF marine programme.

\section{Compliance with ethical standards}

Conflicts of interest The authors declare that they have no conflicts of interest.

Ethical standards Permission for this work was provided by the Environment Agency Abu Dhabi and the Ras Al Khaimah Environment Protection and Development Authority as part of a greater 4-year study on green sea turtles, and meets the ethical standards of both entities, as well as those of Emirates Nature - WWF, and of the Marine Research Foundation for the care and handling of animals. Our study also adopted recommended research procedures recommended by the Marine Turtle Specialist Group of the IUCN Species Survival Commission.

Open Access This article is licensed under a Creative Commons Attribution 4.0 International License, which permits use, sharing, adaptation, distribution and reproduction in any medium or format, as long as you give appropriate credit to the original author(s) and the source, provide a link to the Creative Commons licence, and indicate if changes were made. The images or other third party material in this article are included in the article's Creative Commons licence, unless indicated otherwise in a credit line to the material. If material is not included in the article's Creative Commons licence and your intended use is not permitted by statutory regulation or exceeds the permitted use, you will need to obtain permission directly from the copyright holder. To view a copy of this licence, visit http://creativecommons.org/licenses/by/4.0/.

\section{References}

Alerstam T, Hedenström A, Akesson S (2003) Long-distance migration: evolution and determinants. Oikos 103:247-260

Al-Merghani M, Miller JD, Al-Mansi A, Khushaim O, Pilcher NJ (2000) The green and hawksbill turtles in the Kingdom of Saudi Arabia: synopsis of nesting studies 1986-1997. Fauna Arab 18:369-384

Al-Suweidi AS, Wilson KD, Healy T, Vanneyre L (2012) First contemporary record of green turtle (Chelonia mydas) nesting in the United Arab Emirates. Mar Turtle News1 133:16-17

Benson SR, Dutton PH, Hitipeuw C, Sambar B, Bakerbessy J, Parker D (2007) Post-nesting migrations of leatherback turtles (Dermochelys coriacea) from Jamursba-Medi, Bird's Head Peninsula Indonesia. Chelonian Conserv Biol 6(1):150-154

Bjorndal KA, Bolten AB, Troëng S (2005) Population structure and genetic diversity in green turtles nesting at Tortuguero, Costa Rica, based on mitochondrial DNA control region sequences. Mar Biol 147:1449-1457

Broderick AC, Coyne MS, Fuller WJ, Glen F, Godley BJ (2007) Fidelity and over-wintering of sea turtles. Proc Biol Sci B. https://doi. org/10.1098/rspb.2007.0211

Carreras C, Pascual M, Cardona L, Marco A, Bellido JJ, Castillo JJ, Tomás J, Raga JA, Sanfélix M, Fernández G, Aguilar A (2011) Living together but remaining apart: Atlantic and Mediterranean loggerhead sea turtles (Caretta caretta) in ahared feeding grounds. J Hered 102(6):666-677

Casale P, Freggi D, Gratton P, Argano R, Oliverio M (2008) Mitochondrial DNA reveals regional and interregional importance of the central Mediterranean African shelf for loggerhead sea turtles (Caretta caretta). Scient Mar 72(3):541-548

Casale P, Affronte M, Scaravelli D, Lazar B, Vallini C, Luschi P (2012a) Foraging areas, movement patterns and habitat connectivity of juvenile loggerhead turtles (Caretta caretta) tracked from the Adriatic Sea. Mar Biol 159:1527-1535

Casale P, Broderick AC, Freggi D, Mencacci R, Fuller WJ, Godley BJ, Luschi P (2012b) Long-term residence of juvenile loggerhead turtles to foraging areas: a potential conservation hotspot in the Mediterranean. Aquatic Conserv Mar Freshw Ecosyst 22(2):144-154

Casale P, Freggi D, Cinà A, Rocco M (2013) Spatio-temporal distribution and migration of adult male loggerhead sea turtles (Caretta caretta) in the Mediterranean Sea: further evidence of the importance of neritic habitats off North Africa. Mar Biol 160:703-718

Chaloupka MY, Limpus CJ (2001) Trends in the abundance of sea turtles resident in Southern Great Barrier Reef waters. Biol Conserv 102:235-249

Chevallier D, Girondot M, Berzins R, Chevalier J, de Thoisy B, Fretey J, Kelle L, Lebreton JD (2020) Survival and breeding interval of an endangered marine vertebrate, the leatherback turtle Dermochelys coriacea, in French Guiana. Endanger Sp Res 41:153-165

Coyne MS, Godley BJ (2005) Satellite tracking and analysis tool (STAT): an integrated system for archiving, analyzing, and mapping animal tracking data. Mar Ecol Prog Ser 301:1-7

Crouse D, Crowder L, Caswell H (1987) A stage-based population model for Loggerhead sea turtles and implications for conservation. Ecol 68(5):1412-1423

Dunn DC, Harrison AL, Curtice C, DeLand S, Donnelly B, Fujioka E, Heywood E, Kot CY, Poulin S, Whitten M, Åkesson S, Alberini S, Appeltans W, Arcos JM, Bailey H, Ballance LT, Block B, Blondin H, Boustany AM, Brenner J, Catry P, Cejudo D, Cleary J, Corkeron P, Costa DP, Coyne M, Ortuño Crespo G, Davies TE, Dias MP, Douvere F, Ferretti F, Formia A, Freestone D, Friedlaender AS, Frisch-Nwakanma H, Barrio Froján C, Gjerde KM, Glowka L, Godley BJ, Gonzalez-Solis J, Granadeiro JP, Gunn V, Hashimoto Y, Hawkes LM, Hays GC, Hazin C, Jimenez J, Johnson DE, Luschi P, Maxwell SM, McClellan C, Modest M, Notarbartolo di Sciara G, Herrero Palacio A, Palacios DM, Pauly A, Rayner M, Rees AF, Ross Salazar E, Secor D, Sequeira AMM, Spalding M, Spina F, Van Parijs S, Wallace B, Varo-Cruz N, Virtue M, Weimerskirch H, Wilson L, Woodward B, Halpin PN (2019) The importance of migratory connectivity for global ocean policy. Proc R Soc B. https://doi.org/10.1098/rspb.2019.1472

Dutton PH, LeRoux RA, LaCasella EL, Seminof JA, Eguchi T, Dutton DL (2018) Genetic analysis and satellite tracking reveal origin of the green turtles in San Diego Bay. Mar Biol. https://doi. org/10.1007/s00227-018-3446-4

EAD (2007) Marine Environment and Resources of Abu Dhabi. In: Abdessalaam T (ed) Environment Agency Abu Dhabi. Motivate Publishing, Abu Dhabi

Godley BJ, Blumenthal JM, Broderick AC, Coyne MS, Godfrey MH, Hawkes LA, Witt MJ (2008) Satellite tracking of sea turtles: Where have we been and where do we go next? Endang Species Res 4:3-22

Hamann M, Limpus CJ, Owens DW (2003) Reproductive cycles of males and females. Biol Sea Turtles 2:135-161

Hamann M, Godfrey MH, Seminoff JA, Arthur K, Barata PCR, Bjorndal KA, Bolten AB, Broderick A, Campbell LM, Carreras C, Casale P, Chaloupka M, Chan SKF, Coyne MS, Crowder LB, Diez CE, Dutton PH, Epperly SP, FitzSimmons NN, Formia A, Girondot M, Hays GC, Cheng IS, Kaska Y, Lewison R, Mortimer JA, Nichols WJ, Reina RD, Shanker K, Spotila JR, Tomas J, Wallace BP, Work TM, Zbinden J, Godley BJ (2010) Global research priorities for sea turtles: informing management and conservation in the 21st century. Endang Sp Res 11:245-269. https://doi. org/10.3354/esr00279 
Hart KM, Fujisaki I (2010) Satellite tracking reveals habitat use by juvenile green sea turtles Chelonia mydas in the Everglades, Florida, USA. Endang Sp Res 11:221-232

Hasbún CR, Lawrence AJ, Samour JH, Al Ghais SM (2000) Preliminary observations on the biology of green turtles, Chelonia mydas, from the United Arab Emirates. Aquatic Conserv 10(5):311-322

Hays GC, Bradshaw CJA, James MC, Lovell P, Simms DW (2007) Why do Argos satellite tags on marine animals stop transmitting? J Exp Mar Biol Ecol 349:52-60

Hebbelmann L, Pereira J, Yagmour F, Al Ali A (2016) New records of sea turtle nesting at Al Qurm Wa Lehhfaiiah protected area beach after a 30-year absence. Mar Turtle Newsl 150:7-9

Heppell SS, Snover ML, Crowder LB (2003) Sea turtle population ecology. Biol Sea Turtles 2:275-306

James MC, Eckert SA, Myers RA (2005) Migratory and reproductive movements of male leatherback turtles (Dermochelys coriacea). Mar Biol 147:845-853. https://doi.org/10.1007/s0022 7-005-1581-1

Jensen MP, Miller J, FitzSimmons NN, Al-Merghani M (2019) Identification of Chelonia mydas populations in the Kingdom of Saudi Arabia through regional genetic analyses. Mar Turtle Newsl 156:16-20

Lamine EB, Mateos-Molina D, Antonopoulou M, Burt JA, Das HS, Javed S, Muzaffar S, Giakoumi S (2020) Identifying coastal and marine priority areas for conservation in the United Arab Emirates. Biod Conserv. https://doi.org/10.1007/s10531-020-02007-4

Limpus CJ (2009) A biological review of Australian marine turtle species Green turtle, Chelonia mydas (Linnaeus). Queensland Environ Protect Agency 2:10-96

Limpus CJ, Limpus DJ (2001) The loggerhead turtle, Caretta caretta, in Queensland: breeding migrations and fidelity to a warm temperate feeding area. Chelonian Conserv Biol 4:142-153

Limpus C, Nicholls N (1988) The Southern Oscillation regulates the annual numbers of green turtles (Chelonia mydas) breeding around Northern Australia. Austr Wildl Res 15:157-161

Limpus CJ, Reed PC (1985) The green turtle, Chelonia mydas, in Queensland: a preliminary description of the population structure in a coral reef feeding ground. In: Ehmann H (ed) Grigg G, R Shine R. Biology of Australasian Frogs and Reptiles. Royal Zool Soc New South Wales and Surrey Beatty Sons, Sydney pp, pp 47-52

Limpus CJ, Miller JD, Parmenter CJ, Reimer D, McLachland N, Webb R (1992) Migration of green (Chelonia mydas) and loggerhead (Caretta caretta) turtles to and from eastern Australian rookeries. Wildl Res 19:347-358

Limpus CJ, Limpus DJ, Arthur KE, Parmenter CJ (2005) Monitoring Green Turtle Population Dynamics in Shoalwater Bay: 20002004. Research Publishing Wildlife Service, Queensland Parks

Mancini A, Phillott A, Rees A (2019) Chelonia mydas North Indian Ocean subpopulation. In IUCN Red List of Threatened Species 2019. https://www.iucnredlist.org/species/142121108/142122995 (Accessed 04 Aug 2019).

Maneja RH, Miller JD, Alcaria A, Basali AU, Dagoy JJ, Flandez AVB, Alzoghiby IA, Bass Jr. WH, Kattan YM, Loughland RA, AlAbdulkader KA, Qurban MAB (2018). Satellite tagging reveals migratory routes of post-nesting hawksbill and green sea turtles towards the foraging areas in the northern Arabian Gulf. In: Proceedings of the 38th Annual Symposium on Sea Turtle Biology and Conservation (T Ishihara \& K Okamoto, compilers) Kobe, Japan $\mathrm{p} 35$

Martin TG, Chadès I, Arcese P, Marra PP, Possingham HP, Ryan Norris D (2007) Optimal conservation of migratory species. PLoS ONE 2(8):e751. https://doi.org/10.1371/journal.pone.0000751

Metcalfe K, Bréheret N, Bal G, Eva Chauvet E, Doherty PD, Formia A, Girard A, Mavoungou JG, Parnell RJ, Pikesley SK, Godley BJ (2010) Tracking foraging green turtles in the Republic of the
Congo: insights into spatial ecology from a data poor region. Oryx. https://doi.org/10.1017/S0030605319000309

Miller JD (1989) Marine Turtles Volume 1: an assessment of the conservation status of marine turtles in the Kingdom of Saudi Arabia. MEPA, Jeddah Saudi Arabia

Miller JD (1997) Reproduction in sea turtles. In: Musick J (ed) The Biology of Sea Turtles. CRC Press, Boca Raton, pp 51-82

Miller JD, Limpus CL (2003) Ontogeny of marine turtle gonads. In: Musick JA, Wyneken J (eds) The Biology of Sea Turtles Volume II. CRC Press, Boca Raton, pp 199-224

Miller JD, Preen A, Loughland RA, Youssef AM, Darwish AM (2004) Marine turtles and sea snakes in Abu Dhabi Emirate. In: Fadel S, Almehdi A, Hellyer P (eds) Marine Atlas of Abu Dhabi. Emirates Heritage Club, Abu Dhabi, UAE, pp 184-201

Mingozzi T, Mencacci R, Cerritelli G, Giunchi D, Luschi P (2016) Living between widely separated areas: long-term monitoring of Mediterranean loggerhead turtles sheds light on cryptic aspects of females spatial ecology. J Exp Mar Biol Ecol 485:8-17. https ://doi.org/10.1016/j.jembe.2016.08.007

Mobaraki A (2004) Green turtle nesting on the Gulf of Oman coastline of the Islamic Republic of Iran. Mar Turtle Newsl 104:11

Mobaraki A, Ghasemi M, Kami HG (2019) First record of green sea turtle nesting at Sheedvar Island, Persian Gulf. Iran Indian Ocean Turtle Newsl 30:5-7

Musick JA, Limpus CJ (1997) Habitat utilization and migration in juvenile sea turtles. In: Musick J (ed) The Biology of Sea Turtles. CRC Press, Boca Raton pp, pp 137-163

Nasher K, Al Jumaily M (2015) Steps to building long term sea turtle conservation programme in Yemen. Wildl Middle East News 7(2):1-2

Phillips RC (2003) The Arabian Gulf and Arabian Region. In: Short FT (ed) World Atlas of Seagrasses. UNEP WCMC, London pp, pp 74-81

Pilcher NJ (2000) The green turtle (Chelonia mydas) in the Saudi Arabian Gulf. Chelonian Conserv Biol 3:730-734

Pilcher NJ, Antonopoulou M, Perry L, Abdel-Moati MA, Abdessalaam TZ, Albeldawi M, Al Ansi M, Al-Mohannadi SF, Al Zahlawi N, Baldwin R, Chikhi A, Das HS, Hamza A, Kerr OJ, Al Kiyumi A, Mobaraki A, Al Suwaidi HS, Al Suweidi AS, Sawaf M, Tourenq C, Williams J, Willson A (2014a) Identification of Important Turtle Areas (ITAs) for hawksbill turtles in the Arabian Region. J Exp Mar Biol Ecol 460:89-99

Pilcher NJ, Perry L, Antonopoulou M, Abdel-Moati MA, Al Abdessalaam TZ, Albeldawi M, Al Ansi M, Al-Mohannadi SF, Baldwin R, Chikhi A, Das HS, Hamza A, Kerr OJ, Al Kiyumi A, Mobaraki A, Al Suwaidi HS, Al Suweidi AS, Sawaf M, Tourenq C, Williams J, Willson A (2014b) Short-term behavioural responses to thermal stress by hawksbill turtles in the Arabian region. J Exp Mar Biol Ecol 457:190-198

Pilcher NJ, Al-Maslamani I, Williams J, Gasang R, Chikhi A (2015) Population structure of marine turtles in coastal waters of Qatar. Endang Sp Res 28(2):163-174. https://doi.org/10.3354/esr00 688

Pilcher NJ, Rodriguez-Zarate CJ, Antonopoulou MA, Mateos-Molina D, Das HS, Bugla I (2020) Combining laparoscopy and satellite tracking: successful round-trip tracking of female green turtles from feeding areas to nesting grounds and back. Global Ecol Cons. https://doi.org/10.1016/j.gecco.2020.e01169

Ramsar S (2018) Ramsar COP13 Resolution "The enhanced conservation of coastal marine turtle habitats and the designation of key areas as Ramsar Sites." United Arab Emirates, Dubai

Rees AF, Al Kiyumi A, Broderick AC, Papathanasopoulou N, Godley BJ (2012) Each to their own: Inter-specific differences in migrations of Masirah Island turtles. Chelonian Conserv Biol 11(2):243-248 
Rees AF, Al Hafez A, Lloyd JR, Papathansopoulou N, Godley BJ (2013) Green turtles, Chelonia mydas, in Kuwait: Nesting and movements. Chelonian Conserv Biol 12(1):157-163

Rees AF, Papathanasopoulou N, Godley BJ (2019) Tracking hawksbill and green sea turtles in Kuwait reveals variability in migratory and residency strategies. Indian Ocean Turtle Newsl 28:23-26

Robinson DP, Jabado RW, Rohner CA, Pierce SJ, Hyland KP, Baverstock WR (2017) Satellite tagging of rehabilitated green sea turtles Chelonia mydas from the United Arab Emirates, including the longest tracked journey for the species. PLoS ONE. https://doi. org/10.1371/journal.pone.0184286

Ross JP, Barwani MA (1982) Review of the sea turtles in the Arabian area. In: Bjorndal KA (ed) Biology and conservation of sea turtles. Smithsonian Institution Press, Washington DC, pp 373-383

Saad MA (1999) Hadramaut coast importance in conservation of endangered green turtle. Marine Sciences Resources Research Center, Aden ((Unpublished Report))

Sabah VS, Santandrián-Tomillo P, Reina RD, Spotila JR, Musick JA, Evand DA, Paladino FV (2007) The effect of the El Niño Southern Oscillation on the reproductive frequency of eastern Pacific leatherback turtles. J Appl Ecol 44:395-404

Schofield G, Hobson VJ, Fossette S, Lilley MKS, Katselidis KA, Hays GC (2010) Fidelity to foraging sites, consistency of migration routes and habitat modulation of home range by sea turtles. Div Distrib 16:840-853

Schofield G, Scott R, Dimadi A, Fossette S, Katselidis KA, Koutsoubas D, Lilley MKS, Pantis JD, Karagouni AD, Hays GC (2013) Evidence-based marine protected area planning for a highly mobile endangered marine vertebrate. Biol Conserv 161:101-109

Scott R, Hodgson DJ, Witt MJ, Coyne MS, Adnyana W, Blumenthal JM, Broderick AC, Canbolat AF, Catry P, Ciccione S, Delcroix E,
Hitipeuw C, Luschi P, Pet-Soede L, Pendoley K, Richardson PB, Rees AF, Godley BJ (2012) Global analysis of satellite tracking data shows that adult green turtles are significantly aggregated in Marine Protected Areas. Global Ecol Biogeogr 21:1053-1061

Sherrill-Mix SA, James MC (2008) Evaluating potential tagging effects on leatherback sea turtles. Endang Sp Res 4:187-193

Shimada T, Limpus CJ, Hamann M, Bell I, Esteban N, Groom R, Hays GC (2020) Fidelity to foraging sites after long migrations. J Anim Ecol. https://doi.org/10.1111/1365-2656.13157

Solow AR, Bjorndal KA, Bolten AB (2002) Annual variation in nesting numbers of marine turtles: the effect of sea surface temperature on remigration intervals. Ecol Lett 5:6. https://doi.org/10.104 6/j.1461-0248.2002.00374.x

Southwood Williard A (2007) Physiology as integrated systems. In: Wyneken J, Lohmann K, Musick J (eds) Biology of sea turtles. CRC Press, Boca Raton, pp 1-30

Wallace BP, Williams CL, Paladino FV, Morreale SJ, Lindstrom RT, Spotila JR (2005) Bioenergetics and diving activity of internesting leatherback turtles Dermochelys coriacea at Parque Nacional Marino Las Baulas, Costa Rica. J Exp Biol 208:3873-3884

Watson KP, Granger RA (1998) Hydrodynamic effect of a satellite transmitter on a juvenile green turtle (Chelonia mydas). J Exp Biol 201:2497-2505

Publisher's Note Springer Nature remains neutral with regard to jurisdictional claims in published maps and institutional affiliations. 